\title{
Evaluation of Phenolic Content and Antioxidant Activity of Aqueous Extracts of Three Carica papaya Varieties Cultivated in Senegal
}

\author{
Aïssatou Alioune Gaye*, Oumar Ibn Khatab Cisse, Bou Ndiaye, Nicolas Cyrille Ayessou, \\ Mady Cisse, Codou Mar Diop
}

\begin{abstract}
Laboratoire d'Electrochimie et des Procédés Membranaires, Centre d'Études sur la Sécurité Alimentaire et des Molécules Fonctionnelles (CESAM), Université Cheikh Anta Diop, Dakar, Senegal

Email: ^aissatoualioune1ster@gmail.com, cisse87oumar@hotmail.com, chekbou20@yahoo.fr, nayessou@yahoo.fr, cisse87oumar@hotmail.com,cgmare@gmail.com
\end{abstract}

How to cite this paper: Gaye, A.A., Cisse, O.I.K., Ndiaye, B., Ayessou, N.C., Cisse, M. Diop, C.M. (2019) Evaluation of Phenolic Content and Antioxidant Activity of Aqueous Extracts of Three Carica papaya Varieties Cultivated in Senegal. Food and Nutrition Sciences, 10, 276-289.

https://doi.org/10.4236/fns.2019.103021

Received: January 31, 2019

Accepted: March 11, 2019

Published: March 14, 2019

Copyright $\odot 2019$ by author(s) and Scientific Research Publishing Inc. This work is licensed under the Creative Commons Attribution International License (CC BY 4.0).

http://creativecommons.org/licenses/by/4.0/

\begin{abstract}
The aqueous extracts of different parts (old leaves (OL), young leaves (YL), peels (PE) and delipidated seed residues (DS)) of three varieties of papaya are studied. Extraction conditions are optimized: an extraction time of 20 minutes, a temperature of $70^{\circ} \mathrm{C}$ and a plant material/water mixture of $1 \%$ give the best yield of polyphenol. The amount of polyphenols, flavonoids, saponins and proanthocyanins of each aqueous extract was investigated. Antioxidant activities are measured using two different methods (DPPH and ABTS). The delipidated seeds (DS) of V1 have the highest total phenolic content $(\mathrm{TPC}=72.56 \pm 3.16 \mathrm{mg} \mathrm{GAE} / \mathrm{g}$ ) while they have the lowest total flavonoid content (TFC $=0.22 \pm 0.01$ ). With regard to saponins, the PE of $\mathrm{V} 3$ is much richer in saponins ( $194.03 \pm 15.78 \mathrm{mg} \mathrm{AeE} / \mathrm{g}$ ) than all the other extracts studied. The OL of V2 and PE of V1 contain the most proanthocyanidins with very similar values of $2.51 \pm 0.03 \mathrm{mg} \mathrm{CE} / \mathrm{g}$ and $2.53 \pm 0.34 \mathrm{mg}$ $\mathrm{CE} / \mathrm{g}$ respectively. The study of the antioxidant activities of the extracts showed a correlation between the amount of polyphenols and IC50. DPPH OL and YL V2, which are rich in polyphenols, have the lowest IC50 of 0.072 $\mathrm{mg} / \mathrm{ml}$ and $0.080 \mathrm{mg} / \mathrm{ml}$ respectively, whereas for ABTS we have PE of V1 that is very rich in polyphenols which has the smallest IC50 value of 0.218 $\mathrm{mg} / \mathrm{ml}$.
\end{abstract}

\section{Keywords}

Carica papaya, Extraction, Antioxidant, Polyphenols, Flavonoids, Proanthocyanidins, Saponins 


\section{Introduction}

Metabolic and respiration processes generate oxidation reactions in living. During these metabolic reactions, the use of oxygen can require highly reactive oxygen forms (ROS) such as free radicals or peroxidised $\left(\mathrm{O}_{2}^{-}, \mathrm{HO}, \mathrm{H}_{2} \mathrm{O}_{2}, \mathrm{ONOO}^{-}\right.$, ${ }^{1} \mathrm{O}_{2}$, $\mathrm{ROOH}$, NO) [1]. Their actions on macromolecules can induce often irreversible damage [2] [3] [4]. It is generally recognized that the presence of free radicals contributes to the occurrence of serious diseases such as cancer, cirrhosis, diabetes, emphysema, cardiovascular diseases and rheumatism [5] [6] [7] [8]. Since the process of onset of ROS is natural, one must try to control their concentrations in the human body in particular. For this purpose it is necessary to provide supplements able to neutralize them without generating harmful species. This is possible with antioxidants such as polyphenols [9] [10] [11] [12]. Polyphenols are a set of chemical compounds such as phenolic acids, coumarin, flavonoids, anthocyanin, tannin, lignin, which are widespread in the plant kingdom and derived from the secondary metabolism of plants [13] [14] [15] [16]. Synthetic antioxidants can also be used but unfortunately, their use is very restricted [17] [18] [19] [20]. For several years natural antioxidants from fruit and vegetable plants have been widely examined to understand their role in the reduction of ROS in cells [11] [21] [22] [23]. Usually, only fruits and vegetables were consumed for their bioactive components but investigations showed that other organs of the plant (leaves, bark, peelings, roots...) can contain bioactive chemical species, in particular polyphenolic compounds [24] [25] [26]. Thus these organs which constituted a problem of waste management can be used advantageously to extract the bioactive species which have a rather important added value. In this context, Carica papaya known for its nutritional and therapeutics interests offers an advantageous opportunity. In fact, leaves are used as to relieve nerve pain, asthma attacks or sugar's levels control [27]. The seeds are used in the treatment of ulcers [28], diabetes [29], hypertension [30], hypercholesterolemia [31] and liver diseases.

The principal aim of this study is to optimize the extraction of polyphenols in the different parts (old leaves (OL), young leaves (YL), peels (PE) and defatted seeds (DS)) of three varieties of Carica papaya. Secondary, the different categories of molecules (polyphenols, flavonoids...) of interest are quantified and the antioxidant activities of the three varieties are studied according to the different parts.

\section{Experimental}

\subsection{Plant Material}

Three varieties of Carica papaya L. were harvest at the Sébikhotane protected forest (region of Dakar in Senegal $14^{\circ} 43^{\prime} 14.4^{\prime \prime N}, 17^{\circ} 08^{\prime} 16.4^{\prime \prime} \mathrm{W}$ ): Ordinary (V1), Red Lady (V2) and Sunrise (V3). Old (OL) and young (YL) leaves, the seed (DS) and the peels (PE) from mature fruits were collected. The ordinary variety produces round fruits with a yellowish flesh while Sunrise ones are oblong with red 
flesh, fragrant, juicy and sweet. The Red Lady fruits are also oblong with a sweet-fruited cultivar, but they are three to four times larger than the fruit of the Sunrise variety. Samples were rinsed with water and distillate water and were air-dried free for 3 days. After this process, they were dried at $55^{\circ} \mathrm{C}$ during 48 hours in an oven. Then, the different organs of $C$. papaya L. (OL, YL and PE) have been finely ground using a grinder and stored at $4^{\circ} \mathrm{C}$ for later use. The seeds were ground and defatted with hexane and the residue (DS: defatted seed) was air dried and stored at $4^{\circ} \mathrm{C}$ for further uses.

\subsection{Extraction Process}

Extraction process was done according to the procedure used by Vuong et al. [32]. TPC is used as response value. For the determination of optimum temperature leaves were crushed and $0.5 \mathrm{~g}$ of powder is extracted in $50 \mathrm{ml}$ of distillate water at variable temperatures $\left(50^{\circ} \mathrm{C}, 60^{\circ} \mathrm{C}, 70^{\circ} \mathrm{C}, 80^{\circ} \mathrm{C}\right.$ and $\left.90^{\circ} \mathrm{C}\right)$ for $20 \mathrm{mi}-$ nutes using an agitated water bath whose temperature is well controlled. This optimal temperature is used to determine the optimum extraction duration. Then $0.5 \mathrm{~g}$ of papaya leaves' powder was extracted with $50 \mathrm{ml}$ of water at the optimum temperature with varying extraction times $(5,10,20$ and $30 \mathrm{~min})$. The optimum temperature and the optimum duration are used to determine the optimal ratio in the range of $0.5-1.0-1.25-2.5-3.25$ and $5.0 \mathrm{~g}$ with $50 \mathrm{ml}$ of water. For further study, the optimal values of these three parameters are used. Prior the extraction, the seeds were defatted by hexane. Then the extract was filtered through a Whatmann filter paper $\mathrm{N}^{\circ} 1$. The extract obtained was stored at $4^{\circ} \mathrm{C}$ for further use.

\subsection{Determination of the Total Phenolic Content}

The assay was due according to Mohdaly et al. [33] with some modifications. A test sample of $200 \mu \mathrm{l}$ final (several dilution were made) was mixed with $150 \mu \mathrm{L}$ of Folin-Ciocalteu reagent, $600 \mu \mathrm{l}$ of $\mathrm{Na}_{2} \mathrm{CO}_{3} 20 \%$ and $2.32 \mathrm{ml}$ of distillate water. After $1 \mathrm{~h}$ of incubation in the darkness at room temperature, the absorbance was read at $760 \mathrm{~nm}$ with a Perkin-Elmer UV/Visible spectrophotometer Lambda 365. Gallic acid (GA) was used as a standard. The results were expressed as mg $\mathrm{GAE} / \mathrm{g} \pm$ Standard deviations.

\subsection{Determination of the Flavonoids Contents}

According to the method of Ordoñez et al. [34], $2.5 \mathrm{ml}$ of sample were mixed with $2.5 \mathrm{ml}$ of an ethanolic solution of $\mathrm{AlCl}_{3}$. After $1 \mathrm{~h}$ of incubation in the darkness at room temperature, the absorbance was read at $425 \mathrm{~nm}$ with a Perkin-Elmer UV/Visible spectrophotometer Lambda 365. Quercetin (Q) was used as a standard. The results were expressed as $\mathrm{mg} \mathrm{QE} / \mathrm{g} \pm$ Standard deviations.

\subsection{Determination of Saponins Content}

The procedure developed by Vuong et al. [32] was used with a little modifiction. 
$0.5 \mathrm{ml}$ of sample (dilutions were made if they are required) were mixed with 0.5 $\mathrm{ml}$ of a vanillin ethanolic solution and $5 \mathrm{ml}$ of $\mathrm{H}_{2} \mathrm{SO}_{4}$ at $72 \%$. The samples were incubated at $70^{\circ} \mathrm{C}$ in a water bath during 10 minutes. After that they were cooled slowly at room temperature. The absorbance was measured at $560 \mathrm{~nm}$ with a Perkin-Elmer UV/Visible Spectrophotometer Lambda 365. Aescin was used as a standard and results were expressed as $\mathrm{mg} \mathrm{AeE} / \mathrm{g} \pm$ Standard deviations.

\subsection{Determination of Proanthocyanidins}

The proanthocyanidin content was determined according to the procedure described by Li et al (2006) [35]. To $0.5 \mathrm{~mL}$ of diluted sample, $3 \mathrm{~mL}$ of $4 \%(\mathrm{w} / \mathrm{v})$ vanillin is added before adding this mixture to $1.5 \mathrm{~mL}$ of concentrated $\mathrm{HCl}$. This mixture is incubated at room temperature for $15 \mathrm{~min}$ before reading the absorbance at $500 \mathrm{~nm}$. Catechin (C) was used as standard and the results are expressed as $\mathrm{mg} \mathrm{CE} / \mathrm{g} \pm$ Standard deviations.

\subsection{Antioxidant Capacity}

\subsubsection{DPPH Free Radical Scavenging}

Before determining the IC50 we have to determine the TEAC (Trolox Equivalent Antioxidant Capacity) according to Akhtar et al. [36] with modifications. Firstly, $0.1014 \mathrm{mM}$ of fresh DPPH in methanol was prepared. Trolox was used as a standard; dilutions were made to have a final volume of $200 \mu \mathrm{l}$. The different extracts or Trolox solutions $(200 \mu \mathrm{l})$ were mixed with $3.8 \mathrm{ml}$ of DPPH. After 30 minutes of incubation in the dark at room temperature we read the absorbance at $517 \mathrm{~nm}$. Next, we made adequate dilution to determine the IC50. Results were expressed as $\mu \mathrm{g}$ TrE/g \pm Standard deviations. DPPH scavenging activity was determined by calculating the percentage of inhibition:

$$
\text { Scavenging activity }=\frac{\text { Absorbance }_{\text {control }}-\text { Absorbance }_{\text {sample }}}{\text { Absorbance }_{\text {control }}} \times 100
$$

\subsubsection{ABTS Free Cation Radical Scavenging}

Like DPPH assay, we have to determine the TEAC and the IC50. The assay developed by Thaipong et al. [37] with modifications was used. A stock solution by mixing an equal volume of a $3 \mathrm{mM}$ potassium persulfate $\left(\mathrm{K}_{2} \mathrm{~S}_{2} \mathrm{O}_{8}\right)$ solution with ABTS solution $8 \mathrm{mM}$ was prepared and stocked in the darkness during $16 \mathrm{~h}$ before use. A working solution is prepared by diluting the stock solution with a phosphate buffer $(0.2 \mathrm{M}, \mathrm{pH} 7.4,150 \mathrm{mM} \mathrm{NaCl})$ up to get an absorbance of 1.2 at $734 \mathrm{~nm}$. The different extracts or Trolox solutions $(100 \mu \mathrm{l})$ were mixed with $2.9 \mathrm{ml}$ of ABTS working solution. 30 minutes after incubation absorbance is read at $735 \mathrm{~nm}$. Then, adequate dilution is made to determine the IC50. Results were expressed as $\mu \mathrm{g} \mathrm{TrE} / \mathrm{g} \pm$ Standard deviations. ABTS scavenging activity was determined by calculating the percentage of inhibition (Equation (1)).

\subsection{Statistical Analyses}

All the measurements were carried out in triplicate. The mean values and stan- 
dard deviations were calculated and the data were expressed as mean \pm SD. Xlstat 2019 software was used for the data and statistical analysis. Differences were considered significant at the $\mathrm{p}<0.05$ level based on Duncan's new multiple range test.

\section{Results and Discussion}

\subsection{Optimisation of the Extraction}

Under the described experimental conditions, Figure 1 summarizes the variation of polyphenols extraction according the temperature (a), the duration (b) and the ratio (c). It shows that the temperature, the time and the ratio parameters have an influence on the yield of the extraction of polyphenols during the aqueous extraction of papaya leaves. The yield increases with the temperature to reach a maximum at $70^{\circ} \mathrm{C}$ which will be considered as the optimum. This observation is consistent with that reported by Vuong et al. [32]. Similarly, the extractability of the polyphenols increases and reaches a maximum at 20 minutes. Beyond this extraction time, there is a degradation of the yield of polyphenols. Therefore, the optimal temperature of $70^{\circ} \mathrm{C}$ and the extraction time of $20 \mathrm{mi}-$ nutes are chosen to study the influence of the ratio on material plant/water $(\mathrm{w} / \mathrm{v})$. It is observed in Figure 1 (c) that the extraction efficiency is better for the 1/100 ratio. This result seem to be logical as it is reported by Gertenbach et al. [38] that the lower the plant/water ratio (w/v), the higher is the rate of extraction. Indeed, there is a concentration gradient between the phenolic compounds inside the foliar particles and the ones located on the surface, thus leading to an acceleration of the extraction process at high dilution.

For the present work the extractions are carried out at a temperature of $70^{\circ} \mathrm{C}$ for 20 minutes in a vegetable/water ratio of $1 / 100$ to quantify total phenolic, total flavonoid, saponins and proanthocyanidins.

\subsection{Total Phenolic and Total Flavonoid Content from Three Varieties of Carica papaya}

The results of the quantitative determination of the polyphenol contents of the
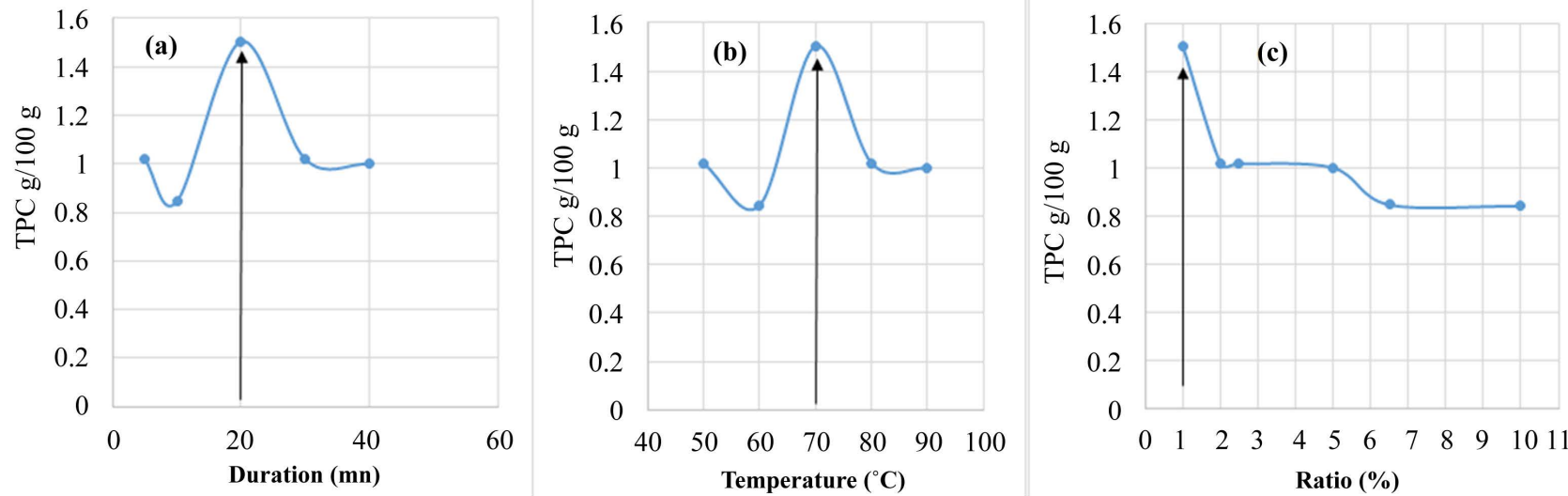

Figure 1. Optimisation parameters of the aqueous extraction. (a) Duration; (b) Temperature; (c) Ratio. 
different varieties are given in Table 1 . It is noted that for ordinary variety (V1), the residue of defatted seeds (DS) is much richer in polyphenols (72.56 \pm 3.16 mg GAE/g) followed by young leaves (YL) (38.03 $\pm 1.18 \mathrm{mg} \mathrm{GAE} / \mathrm{g})$ and old leaves (OL) (29.75 $\pm 1.22 \mathrm{mg} \mathrm{GAE} / \mathrm{g})$; the peels $(\mathrm{PE})$ are half as rich in polyphenols (19.87 $\pm 0.26 \mathrm{mg} \mathrm{GAE} / \mathrm{g})$ as the young leaves. Unlike V1, the residue of defatted seeds (DS) of Red Lady variety (V2) is less rich in polyphenols (9.61 \pm 3.81 $\mathrm{mg} \mathrm{GAE} / \mathrm{g})$ than all other parts of the plant; young leaves are richer $(55.24 \pm 3.14$ $\mathrm{mg}$ GAE/g), followed by old leaves (53.24 $\pm 3.02 \mathrm{mg} \mathrm{GAE} / \mathrm{g})$ and peels (15.53 \pm $5.93 \mathrm{mg} \mathrm{GAE} / \mathrm{g}$ ) remaining poor. In Sunrise variety (V3), the old leaves are richer in polyphenols ( $41.77 \pm 0.96 \mathrm{mg} \mathrm{GAE} / \mathrm{g}$ ) while the peels are the poorest (23.64 $\pm 1.28 \mathrm{mg} \mathrm{GAE} / \mathrm{g}$ ); the defatted seeds and the young leaves have comparable polyphenol levels ( $38.28 \pm 1.34$ and $38.56 \pm 1.61 \mathrm{mg} \mathrm{GAE} / \mathrm{g})$. It is observed that the defatted seeds of V1 are twice as rich in polyphenols as V3 ones and that it is three times richer than that of V2 which is poor in polyphenols. In V2 the polyphenols are found in the leaves whereas in V1 the seeds contain almost as many polyphenols as all the other parts of the plant combined. For V3 the polyphenols are fairly homogeneously distributed in the leaves and seeds. It should be noted that for varieties V2 and V3 the total polyphenol content (TPC) of young leaves and the old leaves are comparable contrary to V1 for which the TPC of the young leaves is higher than the TPC of the old leaves. The three varieties studied in this work have a TPC that is higher than Carica studied by Vuong et al. [32]. Leaves of a variety of $C$. papaya, cultivated in Pakistan [39], give TPC value of $49.94 \pm 0.60 \mathrm{mg} \mathrm{AeE} / \mathrm{g}$ which is less than the values found for OL and YL of V2 and higher than those for OL and YL of V1 and V3. The TPC $(32.23 \pm 0.64 \mathrm{mg}$ AeE/g) of the peels of the Pakistan's variety is greater than those of the three varieties used in this study while the seeds' TPC $(27.94 \pm 0.09 \mathrm{mg} \mathrm{AeE} / \mathrm{g})$ is very low compared to the TPC value of the DS of V1 and V3.

For all three varieties, flavonoid levels are low (Table 1). This can be explained

Table 1. Total phenolic and total flavonoid content of three varieties of Carica papaya.

\begin{tabular}{ccccc}
\hline \multicolumn{5}{c}{ Total phenolic content $(\mathrm{mg} \mathrm{GAE} / \mathrm{g})$} \\
\hline OL & YL & PE & DS \\
\hline V1 & $29.75 \pm 1.22^{\mathrm{a}}$ & $38.03 \pm 1.18^{\mathrm{b}}$ & $19.87 \pm 0.26^{\mathrm{c}}$ & $72.56 \pm 3.16^{\mathrm{d}}$ \\
V3 & $53.24 \pm 3.02^{\mathrm{e}}$ & $55.24 \pm 3.14^{\mathrm{e}}$ & $15.53 \pm 5.93^{\mathrm{f}}$ & $9.61 \pm 3.81^{\mathrm{g}}$ \\
\hline & $41.77 \pm 0.96^{\mathrm{h}}$ & $38.56 \pm 1.61^{\mathrm{b}, \mathrm{h}}$ & $23.64 \pm 1.29^{\mathrm{j}}$ & $38.28 \pm 1.34^{\mathrm{b}}$ \\
\hline V1 & $1.11 \pm 0.077^{\mathrm{a}}$ & $1.01 \pm 0.009^{\mathrm{a}}$ & $0.34 \pm 0.050^{\mathrm{b}}$ & $0.22 \pm 0.010^{\mathrm{b}}$ \\
V2 & $1.46 \pm 0.047^{\mathrm{c}}$ & $1.39 \pm 0.014^{\mathrm{d}}$ & $0.23 \pm 0.004^{\mathrm{e}}$ & $0.36 \pm 0.013^{\mathrm{e}}$ \\
V3 & $1.39 \pm 1.970^{\mathrm{d}}$ & $0.99 \pm 0.010^{\mathrm{g}}$ & $0.23 \pm 0.006^{\mathrm{h}}$ & $1.01 \pm 0.030^{\mathrm{i}}$ \\
\hline
\end{tabular}

Legend: Ordinary (V1), Red Lady (V2) and Sunrise (V3). OL: Old leaves, YL: Young leaves; PE: Peels and DS: defatted seeds. Values with different letters in superscript in column showed the significant differences at the significance level of p-value of 0.05 or $0.001^{\star}$. 
by the low solubility of flavonoids in water which is a very polar solvent. Indeed, the flavonoids which are low polar molecules are more soluble in the organic solvents and little and medium polar solvents. For all varieties, flavonoid levels of OL and YL are comparable and range between $1.10 \mathrm{mg} \mathrm{QE} /$ and $1.50 \mathrm{mg} \mathrm{QE} / \mathrm{g}$. These values are lower than the value reported in the literature $(3.33 \mathrm{mg} / \mathrm{g})$ for young leaves of the papaya variety which growth in Malaysia [40]. The TFC of aqueous extracts of defatted seeds $(0.22 \mathrm{mg} \mathrm{QE} / \mathrm{g}-1.01 \mathrm{mg} \mathrm{QE} / \mathrm{g})$ are greater than the TFC of aqueous extract of the seeds of the Malaysian variety [40]. The TFC of PE are between $0.23 \mathrm{mg} \mathrm{QE} / \mathrm{g}$ and $0.35 \mathrm{mg} \mathrm{QE} / \mathrm{g}$ and are higher than the value reported $(0.056 \mathrm{mg} / \mathrm{g})$ for the Carica papaya L. var solo 8 variety that is cultivated in Ivory Coast [41].

\subsection{Saponins Content of Three Varieties of Carica papaya}

The peels (PE) and defatted seeds (DS) of sunrise variety (V3) are the richest in saponins $194.03 \pm 15.78$ and $102.92 \pm 26.77 \mathrm{mg} \mathrm{AeE} / \mathrm{g}$ respectively (Table 2). The same observation is noticed for ordinary variety (V1) but with lower values: $87.07 \pm 6.08 \mathrm{mg} \mathrm{AeE} / \mathrm{g}$ for PE and $74.87 \pm 11.77 \mathrm{mg} \mathrm{AeE} / \mathrm{g}$ for DS. For the lady variety (V2), young leaves contain more saponins $(65.88 \pm 5.70 \mathrm{mg} \mathrm{AeE} / \mathrm{g})$ than all the other studied parts of the plant whereas the OL are the poorest saponins content $(49.73 \pm 0.92 \mathrm{mg} \mathrm{AeE} / \mathrm{g}$ ) unlike to the other two varieties (Table 2). This is consistent with the fact that saponins are slightly polar are more compatible with solvents which are less polar than water. These results are in accordance with those reported for the Carica studied by Vuong et al. [32].

\subsection{Proanthocyanidins Content of Aqueous Extracts}

Owing to their low polarity the proanthocyanidins extraction yields in water are low (Table 3). The proanthocyanidins content of OL of the three varieties are comparable and are in the range $2.19-2.51 \mathrm{mg} \mathrm{CE} / \mathrm{g}$ and are slightly greater than those found for YL (1.57 - $2.33 \mathrm{mg} \mathrm{CE} / \mathrm{g}$ ). Peels (PE) and defatted seeds (DS) of V1 are the richest in proanthocyanidins: $2.53 \pm 0.34 \mathrm{mg} \mathrm{CE} / \mathrm{g}$ and $2.50 \pm$ $0.08 \mathrm{mg} \mathrm{CE} / \mathrm{g}$ respectively. For V2, PE and DS are poor with lower values: $1.68 \pm$ $0.16 \mathrm{mg} \mathrm{CE} \mathrm{mg/g} \mathrm{for} \mathrm{PE} \mathrm{and} 1.23 \pm 0.05 \mathrm{mg} \mathrm{CE} / \mathrm{g}$ for DS. For V3 the DS contains much less proanthocyanidins $(1.45 \pm 0.11 \mathrm{mg} \mathrm{CE} / \mathrm{g})$ than all the other studied

Table 2. Saponins content in different organs of three varieties of Carica papaya.

\begin{tabular}{ccccc}
\hline \multicolumn{4}{c}{ Content of Saponins mg AeE/g } \\
\hline OL & YL & PE & DS \\
\hline V1 & $38.31 \pm 5.58^{\mathrm{a}}$ & $66.38 \pm 3.36^{\mathrm{b}}$ & $87.07 \pm 6.08^{\mathrm{c}}$ & $74.87 \pm 11.77^{\mathrm{b}, \mathrm{c}}$ \\
V2 & $49.73 \pm 0.92^{\mathrm{a}}$ & $65.88 \pm 5.70^{\mathrm{b}}$ & $55.61 \pm 7.41^{\mathrm{d}}$ & $51.79 \pm 1.34^{\mathrm{d}}$ \\
V3 & $66.61 \pm 1.97^{\mathrm{b}}$ & $56.35 \pm 12.39^{\mathrm{d}}$ & $194.03 \pm 15.78^{\mathrm{e}}$ & $102.92 \pm 26.77^{\mathrm{f}}$ \\
\hline
\end{tabular}

Legend: Ordinary (V1), Red Lady (V2) and Sunrise (V3). OL: Old leaves, YL: Young leaves; PE: Peels and DS: defatted seeds. Values with different letters in superscript in column showed the significant differences at the significance level of $\mathrm{p}$-value of 0.05 or $0.001^{\star}$. 
Table 3. Proanthocyanidins content in different organs of three varieties of Carica papaya.

\begin{tabular}{ccccc}
\hline \multicolumn{4}{c}{ Content of Proanthocyanidins mg CE/g } \\
\hline OL & YL & PE & DS \\
V1 & $2.23 \pm 0.15^{\mathrm{a}, \mathrm{b}}$ & $2.10 \pm 0.10^{\mathrm{b}, \mathrm{g}}$ & $2.53 \pm 0.34^{\mathrm{a}, \mathrm{h}}$ & $2.50 \pm 0.08^{\mathrm{a}}$ \\
V2 & $2.51 \pm 0.03^{\mathrm{a}, \mathrm{c}, \mathrm{h}}$ & $2.33 \pm 0.12^{\mathrm{a}, \mathrm{c}, \mathrm{g}}$ & $1.68 \pm 0.16^{\mathrm{d}}$ & $1.23 \pm 0.05^{\mathrm{e}}$ \\
V3 & $2.19 \pm 0.06^{\mathrm{a}}$ & $1.57 \pm 0.18^{\mathrm{f}}$ & $1.50 \pm 0.08^{\mathrm{f}}$ & $1.45 \pm 0.11^{\mathrm{f}}$ \\
\hline
\end{tabular}

Legend: Ordinary (V1), Red Lady (V2) and Sunrise (V3). OL: Old leaves, YL: Young leaves; PE: Peels and DS: defatted seeds. Values with different letters in superscript in column showed the significant differences at the significance level of p-value of 0.05 or $0.001^{\star}$.

parts of the plant For V1 the proanthocyanidins quantities are regularly distributed between the different parts of the plant: $2.23 \pm 0.15 \mathrm{mg} \mathrm{CE} / \mathrm{g}-2.53 \pm 0.34$ mg CE/g (Table 3).

\subsection{Antioxidant Capacity and IC50}

Since phenolic compounds are known for their ability to trap free radicals a study of their antioxidant activity and IC50 was carried out for the three varieties of $C$. papaya. Table 4 summarizes their results.

$\mathrm{DPPH}$, which is a stable radical, is widely used to evaluate free radical scavenging ability [42] [43]. Globally, the results show that V2 has a better antioxidant capacity than V1 and V3 which antioxidant's activities seem similar. The trend can be seen with OL and YL but not with PE and DS. The antioxidant capacity is slightly higher in OL than YL for V2 and V3 $(8.92 \pm 0.21 \mathrm{mg} \mathrm{TrE} / \mathrm{g}$ for OL and $8.39 \pm 0.08 \mathrm{mg} \mathrm{TrE} / \mathrm{g}$ for YL of V2); $(5.58 \pm 0.42 \mathrm{mg} \mathrm{TrE} / \mathrm{g}$ for OL and $4.01 \pm 0.09$ for $\mathrm{YL}$ of $\mathrm{V} 3)$, while inverted tendency is noticed for $\mathrm{V} 1(5.20 \pm 0.20$ $\mathrm{mg} \mathrm{TrE} / \mathrm{g}$ for YL versus $3.85 \pm 0.04 \mathrm{mg} \mathrm{TrE} / \mathrm{g}$ for OL). For V2, the antioxidant capacities are not significantly different $(\mathrm{p}>0.05)$, whereas in V1 and V3 these values are significantly different $(\mathrm{p}<0.05)$.

The trend we observe with OL and YL is not the same with PE and DS. The higher antioxidant capacity for PE is for V3 with $3.69 \pm 0.14 \mathrm{mg} \mathrm{TrE} / \mathrm{g}$ followed by V1 with $2.47 \pm 0.09 \mathrm{mg} \mathrm{TrE} / \mathrm{g}$ and V2 with $1.96 \pm 0.15 \mathrm{mg} \mathrm{TrE} / \mathrm{g}$. It can be noted that for DS, the antioxidant capacities of the three varieties are comparable with a p-value of 0.001 and are in the range $4.06-4.57 \mathrm{mg} \mathrm{TrE} / \mathrm{g}$. The lowest value corresponds to V3 with $4.06 \pm 0.12 \mathrm{mg} \mathrm{TrE} / \mathrm{g}$ while the variety $\mathrm{V} 1$ has the highest DS antioxidant capacity $(4.57 \pm 0.11 \mathrm{mg} \mathrm{TrE} / \mathrm{g})$.

The IC50 cannot be determined with the DPPH's method neither in all organs from V1, V3 nor PE and DS from V2. On the other hand, OL and YL from V2 have a good IC50; OL is better than YL with $0.072 \mathrm{mg} / \mathrm{ml}$ against $0.080 \mathrm{mg} / \mathrm{ml}$.

With the ABTS assay, we determined an IC50 for the different extracts of each variety (Table 4). For variety V2 the different organs studied have highest IC50 values of $0.376 \mathrm{TrE} / \mathrm{ml}(\mathrm{OL}), 0.400 \mathrm{TrE} / \mathrm{ml}(\mathrm{YL}), 0.446 \mathrm{TrE} / \mathrm{ml}(\mathrm{PE})$ and 0.351 $\mathrm{TrE} / \mathrm{ml}$ (DS). Leaves and peels of variety V1 have low IC50 values in the range 
Table 4. The antioxidant capacity (DPPH and ABTS) and IC50 in different organs of three varieties of Carica papaya.

\begin{tabular}{|c|c|c|c|c|c|c|c|}
\hline \multirow[b]{2}{*}{ Variety } & \multirow[b]{2}{*}{ Organ } & \multicolumn{3}{|c|}{ DPPH } & \multicolumn{3}{|c|}{ ABTS } \\
\hline & & mg TrE/g & $\begin{array}{c}\text { IC50 } \\
(\mathrm{mg} / \mathrm{ml})\end{array}$ & $\begin{array}{l}\% \text { Inb max } \\
\text { after } 2 \mathrm{~h} 30\end{array}$ & $\mathrm{mg} \operatorname{TrE} / \mathrm{g}$ & $\begin{array}{c}\mathrm{IC} 50 \\
(\mathrm{mg} / \mathrm{ml})^{*}\end{array}$ & $\begin{array}{l}\% \text { Inb max } \\
\text { after } 2 \text { h } 30\end{array}$ \\
\hline \multirow{4}{*}{ V1 } & OL & $3.85 \pm 0.04^{\mathrm{a}}$ & $\mathrm{n} / \mathrm{a}$ & 39.45 & $46.70 \pm 2.66$ & $0.256^{\mathrm{a}}$ & 77.87 \\
\hline & YL & $5.20 \pm 0.20^{\mathrm{b}}$ & $\mathrm{n} / \mathrm{a}$ & 48.22 & $57.26 \pm 3.10$ & $0.252^{\mathrm{a}}$ & 70.57 \\
\hline & $\mathrm{PE}$ & $2.47 \pm 0.09^{c}$ & $\mathrm{n} / \mathrm{a}$ & 35.15 & $27.89 \pm 0.75$ & $0.218^{\mathrm{a}}$ & 97.57 \\
\hline & DS & $4.57 \pm 0.11^{\mathrm{d}}$ & $\mathrm{n} / \mathrm{a}$ & 40.12 & $83.21 \pm 2.67$ & $0.274^{\mathrm{a}}$ & 69.63 \\
\hline \multirow{4}{*}{$\mathrm{V} 2$} & OL & $8.92 \pm 0.21^{\mathrm{e}}$ & 0.072 & 61.02 & $113.84 \pm 3.80$ & $0.376^{\mathrm{b}}$ & 69.56 \\
\hline & YL & $8.39 \pm 0.08^{\mathrm{e}}$ & 0.080 & 69.96 & $114.95 \pm 0.32$ & $0.400^{\mathrm{b}}$ & 68.30 \\
\hline & PE & $1.96 \pm 0.15^{f}$ & $\mathrm{n} / \mathrm{a}$ & $\begin{array}{c}23.32 \\
\text { (after } 1 \text { h } 30)\end{array}$ & $73.44 \pm 3.16$ & $0.446^{\mathrm{b}}$ & 98.36 \\
\hline & DS & $4.30 \pm 0.05^{\mathrm{d}}$ & $\mathrm{n} / \mathrm{a}$ & $\begin{array}{c}30.26 \\
\text { (after } 1 \text { h } 30)\end{array}$ & $46.71 \pm 1.77$ & $0.351^{\mathrm{b}}$ & 63.82 \\
\hline \multirow{4}{*}{ V3 } & OL & $5.58 \pm 0.42^{g}$ & $\mathrm{n} / \mathrm{a}$ & 48.76 & $56.83 \pm 4.61$ & $0.293^{\mathrm{a}}$ & 71.68 \\
\hline & YL & $4.01 \pm 0.09^{\mathrm{h}}$ & $\mathrm{n} / \mathrm{a}$ & 35.14 & $47.97 \pm 0.86$ & $0.281^{\mathrm{a}}$ & 72.43 \\
\hline & $\mathrm{PE}$ & $3.69 \pm 0.14^{\mathrm{i}}$ & $\mathrm{n} / \mathrm{a}$ & 32.41 & $39.60 \pm 1.19$ & $0.238^{\mathrm{a}}$ & 98.49 \\
\hline & DS & $4.06 \pm 0.12^{\mathrm{d}}$ & $\mathrm{n} / \mathrm{a}$ & 27.34 & $49.26 \pm 1.13$ & $0.269^{\mathrm{a}}$ & 66.87 \\
\hline
\end{tabular}

Values with different letters in superscript in column showed the significant differences at the significance level of p-value of 0.05 or $0.001^{*}$.

$0.256 \mathrm{TrE} / \mathrm{ml}-0.218 \mathrm{mg} \mathrm{TrE} / \mathrm{g}$, with the smallest IC50 for PE. The IC50 values of variety V3 are comparable to the values obtained for V2 and its PE has the smallest value of IC50. However, the antioxidant capacity does not reflect the IC50. Indeed, V2 which has the highest IC50 values has the best antioxidant capacity values for OL, YL and PE with respectively $113.84 \pm 3.80,114.95 \pm 0.32$ and $73.44 \pm 3.16 \mathrm{mg} \mathrm{TrE} / \mathrm{g}$. Indeed, several types of compounds can contribute to the antioxidant capacity of plant materials, including tocopherols, carotenoids and polyphenol compounds. The variation in the antioxidant capacity of the papaya may be due to its geographical origin and to climatic and environmental factors such as temperature, humidity, soil composition, sunlight, and harvesting and storage conditions [44]. The mechanisms involved in the process and the conditions under which reactions with DPPH or ABTS occur may also explain these observations [45] [46].

For DS, V1 has the highest antioxidant capacity with $83.21 \pm 2.67 \mathrm{mg} \mathrm{TrE} / \mathrm{g}$ while V2 and V3 varieties have comparable antioxidant activities of $46.71 \pm 1.77$ $\mathrm{mg} \mathrm{TrE} / \mathrm{g}$ and $49.26 \pm 1.13 \mathrm{mg} \mathrm{TrE} / \mathrm{g}$ respectively. On the other hand for OL and $\mathrm{PE}$, the values are different with respectively $46.70 \pm 2.66 \mathrm{mg} \mathrm{TrE} / \mathrm{g}$ and $27.89 \pm$ $0.75 \mathrm{mg} \mathrm{TrE} / \mathrm{g}$ for V2, $56.83 \pm 4.61 \mathrm{mg} \mathrm{TrE} / \mathrm{g}$ and $39.60 \pm 1.19 \mathrm{mg} \mathrm{TrE} / \mathrm{g}$ for V3. The lowest antioxidant capacity value for YL was found for V3 with $47.97 \pm 0.86$ $\mathrm{mg} \mathrm{TrE} / \mathrm{g}$ versus $57.26 \pm 3.10 \mathrm{mg} \mathrm{TrE} / \mathrm{g}$ for $\mathrm{V} 1$. In previous studies, the antioxidant activities of Carica papaya extracts reported are lowest than our results 
[32]. Other organic solvents such as the extracts of n-hexane, dichloromethane, n-butanol, ethyl acetate, methanol and ethanol showed a significant difference in scavenging activity between the different parts of Carica papaya [32] [39]. According to study of Asghar et al. [39], leaf ethanol extract shows the highest free radical scavenging of DPPH compared to seed and peel extracts. Extracts of $\mathrm{n}$-hexane and $\mathrm{n}$-butanol give the lowest DPPH free radical scavenging probably due to the difference in polarity of the solvents and extracted compounds.

Owing to the quantitative presence of polyphenols and flavonoides in the aqueous extracts of the different studied parts of the plant and the antioxidant activities presented by these extracts, it is conceivable to make formulations in the form of infusion for human consumption. Indeed polyphenols are good substrat for protection against oxidative stress. All these parts of the papaya plant considered as waste can find in this sector a potential valuation at low cost.

\section{Conclusion}

In Senegal, Carica papaya is a widespread tree and several varieties are grown in various regions during all seasons. While only the papaya pulp is consumed in Senegal, this work shows that polyphenols, flavonoids, proanthocyanidins and saponins are present in other organs such as seed, leaves and peels. Their optimal aqueous extraction conditions are reminiscent of the conditions for obtaining infusions. These observations offer interesting prospects for the development of new product in food and nutrition area.

\section{Conflicts of Interest}

The authors declare no conflicts of interest regarding the publication of this paper.

\section{References}

[1] Pandey, V.P., Singh, S., Jaiswal, N., Awasthi, M., Pandey, B. and Dwivedi, U.N. (2013) Papaya Fruit Ripening: ROS Metabolism, Gene Cloning, Characterization and Molecular Docking of Peroxidase. Journal of Molecular Catalysis B Enzymatic, 98, 98-105. https://doi.org/10.1016/j.molcatb.2013.10.005

[2] Pande, D., Negi, R., Khanna, R.S. and Khanna, H.D. (2011) Protein Damage and Antioxidant Status Alterations Caused by Oxidative Injury in Chronic Myeloid Leukemia. Einstein Journal of Biology and Medicine, 27, 55-58.

https://doi.org/10.23861/EJBM20112737

[3] Sharma, P., Jha, A.B., Dubey, R.S. and Pessarakli, M. (2012) Reactive Oxygen Species, Oxidative Damage, and Antioxidative Defense Mechanism in Plants under Stressful Conditions. Journal of Botany, 2012, Article ID: 217037. https://doi.org/10.1155/2012/217037

[4] Rachitha, P., Krupashree, K., Jayashree, G.V., Kandikattu, H.K., Amruta, N., Gopalan, N., Rao, M.K. and Khanum, F. (2018) Chemical Composition, Antioxidant Potential, Macromolecule Damage and Neuroprotective Activity of Convolvulus pluricaulis. Journal of Traditional and Complementary Medicine, 8, 483-496. https://doi.org/10.1016/j.jtcme.2017.11.002 
[5] Pandey, S., Walpole, C., Cabot, P., Shaw, P., Batra, J. and Hewavitharana, A. (2017) Selective Anti-Proliferative Activities of Carica papaya Leaf Juice Extracts against Prostate Cancer. Biomedicine \& Pharmacotherapy, 89, 515-523. https://doi.org/10.1016/j.biopha.2017.02.050

[6] Shashni B. and Nagasaki, Y. (2018) Nitroxide Radical-Containing Nanoparticles Attenuate Tumorigenic Potential of Triple Negative Breast Cancer. Biomaterials, 178, 48-62. https://doi.org/10.1016/j.biomaterials.2018.05.042

[7] Uddin S. and Ahmad, S. (1995) Dietary Antioxidants Protection against Oxidative Stress. Biochemistry Education, 23, 2-7. https://doi.org/10.1016/0307-4412(94)00097-9

[8] Taleb, A., Ahmad, K.A., Ihsan, A.U., Qu, J., Lin, N., Hezam, K., Koju, N., Hui, L. and Qilong, D. (2018) Antioxidant Effects and Mechanism of Silymarin in Oxidative Stress Induced Cardiovascular Diseases. Biomedicine \& Pharmacotherapy, 102, 689-698. https://doi.org/10.1016/j.biopha.2018.03.140

[9] Losada-Barreiro, S. and Bravo-Díaz, C. (2017) Free Radicals and Polyphenols: The Redox Chemistry of Neurodegenerative Diseases. European Journal of Medicinal Chemistry, 133, 379-402. https://doi.org/10.1016/j.ejmech.2017.03.061

[10] Valdez-Morales, M., Cespedes-Acuña, C.L., Valverde, M., Ramírez-Chávez, E. and Paredes-Lopez, O. (2016) Phenolic Compounds, Antioxidant Activity and Lipid Profile of Huitlacoche Mushroom (Ustilago maydis) Produced in Several Maize Genotypes at Different Stages of Development. Plant Foods for Human Nutrition, 71, 436-443. https://doi.org/10.1007/s11130-016-0572-3

[11] Chavarria, D., Silva, T., Martins, D., Bravo, J., Summavielle, T., Garridoc, J. and Borges, F. (2015) Exploring Cinnamic Acid Scaffold: Development of Promising Neuroprotective Lipophilic Antioxidants. MedChemComm, 6, 1043-1053. https://doi.org/10.1039/C5MD00018A

[12] Corcuera, L.A., Amézqueta, S., Arbillaga, L., Vettorazzi, A., Touriño, S. and Torres, J.L. (2012) A Polyphenol-Enriched Cocoa Extract Reduces Free Radicals Produced by Mycotoxins. Food and Chemical Toxicology, 50, 989-995. https://doi.org/10.1016/j.fct.2011.11.052

[13] Chen, F., Liu, C.J., Tschaplinski, T.J. and Zhao, N. (2009) Genomics of Secondary Metabolism in Populus: Interactions with Biotic and Abiotic Environments. Critical Reviews in Plant Sciences, 28, 375-392. https://doi.org/10.1080/07352680903241279

[14] Carluccio, M.A., Calabriso, N., Scoditti, E., Massaro, M. and Caterina, R.D. (2015) Mediterranean Diet Polyphenols. In: The Mediterranean Diet, Academic Press, San Diego, 291-300. https://doi.org/10.1016/B978-0-12-407849-9.00027-0

[15] Yonekura-Sakakibara, K. and Saito, K. (2009) Functional Genomics for Plant Natural Product Biosynthesis. National Product Reports, 26, 1466-1487. https://doi.org/10.1039/b817077k

[16] Siracusa, L. and Ruberto, G. (2014) Plant Polyphenol Profiles as a Tool for Traceability and Valuable Support to Biodiversity. In: Watson, R.R., Ed., Polyphenols in Plants, Academic Press, San Diego, 15-33. https://doi.org/10.1016/B978-0-12-397934-6.00002-4

[17] Chatha, S.A.S., Hussain, A.I., Bajwa, J.U.R. and Sagir, M. (2006) Antioxidant Activity of Different Solvent Extracts of Rice Bran at Accelerated Storage of Sunflower Oil. Journal of Food Lipids, 13, 424-433. https://doi.org/10.1111/j.1745-4522.2006.00068.x

[18] Kamemura, N. (2018) Butylated Hydroxytoluene, a Food Additive, Modulates Membrane Potential and Increases the Susceptibility of Rat Thymocytes to Oxida- 
tive Stress. Computational Toxicology, 6, 32-38. https://doi.org/10.1016/j.comtox.2018.04.001

[19] Thakore, K.N. (2014) Butylated Hydroxyanisole. In: Wexler, P., Ed., Encyclopedia of Toxicology, 3rd Edition, Academic Press, San Diego, 581-582. https://doi.org/10.1016/B978-0-12-386454-3.00262-1

[20] Locatelli, C., Leal, P.C., Yunes, R.A., Nunes, R.J. and Creczynski-Pasa, T.B. (2009) Gallic Acid Ester Derivatives Induce Apoptosis and Cell Adhesion Inhibition in Melanoma Cells: The Relationship between Free Radical Generation, Glutathione Depletion and Cell Death. Chemico-Biological Interactactions, 181, 175-184. https://doi.org/10.1016/j.cbi.2009.06.019

[21] Aryee, A.N.A., Agyei, D. and Akanbi, T.O. (2018) Food for Oxidative Stress Relief: Polyphenols. In: Encyclopedia of Food Chemistry, Reference Module in Food Science, Elsevier, New York, 392-398.

[22] Belščak-Cvitanović, A., Durgo, K., Huđek, A., Bačun-Družina, V. and Komes, D. (2018) Overview of Polyphenols and Their Properties. In: Galanakis, C.M., Ed., Polyphenols: Properties, Recovery, and Applications, Woodhead Publishing, New York, 3-44. https://doi.org/10.1016/B978-0-12-813572-3.00001-4

[23] Kwon, Y. (2018) Food-Derived Polyphenols Inhibit the Growth of Ovarian Cancer Cells Irrespective of Their Ability to Induce Antioxidant Responses. Heliyon, 4, e00753. https://doi.org/10.1016/j.heliyon.2018.e00753

[24] Song, J., Li, D., Liu, C. and Zhang, Y. (2011) Optimized Microwave-Assisted Extraction of Total Phenolics (TP) from Ipomoea Batatas Leaves and Its Antioxidant Activity. Innovative Food Science \& Emerging Technology, 12, 282-287.

https://doi.org/10.1016/j.ifset.2011.03.001

[25] Dahmoune, F., Nayak, B., Moussi, K., Remini, H. and Madani, K. (2015) Optimization of Microwave-Assisted Extraction of Polyphenols from Myrtus communis L. Leaves. Food Chemistry, 166, 585-595. https://doi.org/10.1016/j.foodchem.2014.06.066

[26] Yang, Y.C., Ji, L., Meng, L., Nan, W. and Li, X.L. (2010) Optimisation of Microwave-Assisted Enzymatic Extraction of Corilagin and Geraniin from Geranium sibiricum Linne and Evaluation of Antioxidant Activity. Food Chemistry, 122, 373-380. https://doi.org/10.1016/j.foodchem.2010.02.061

[27] Schlienger, J.L. (2014) Diabète et phytothérapie: les faits. Médecine des Maladies Métaboliques, 8, 101-106. https://doi.org/10.1016/S1957-2557(14)70696-0

[28] Kumar, N.S. and Devi, S. (2017) The Surprising Health Benefits of Papaya Seeds: A Review. Journal of Pharmacognosy and Phytochemistry, 6, 424-429.

[29] Pathak, N., Khan, S., Bhargava, A., Raghuram, G.V., Jain, D. and Panwar, H. (2014) Cancer Chemopreventive Effects of the Flavonoid-Rich Fraction Isolated from $\mathrm{Pa}$ paya Seeds. Nutrition and Cancer, 66, 857-871. https://doi.org/10.1080/01635581.2014.904912

[30] Bestermann, W., Houston, M.C, Basile, J., Egan, B., Ferrario, C.M., Lackland, D., Hawkins, R.G., Reed, J., Rogers, P., Wise, D. and Moore, M.A. (2005) Addressing the Global Cardiovascular Risk of Hypertension, Dyslipidemia, Diabetes Mellitus, and the Metabolic Syndrome in the Southeastern United States, Part II: Treatment Recommendations for Management of the Global Cardiovascular Risk of Hypertension, Dyslipidemia, Diabetes Mellitus, and the Metabolic Syndrome. American Journal of the Medical Sciences, 329, 292-305.

https://doi.org/10.1097/00000441-200506000-00009 
[31] Vij, T. and Prashar, Y. (2015) A Review on Medicinal Properties of Carica papaya Linn. Asian Pacific Journal of Tropical Disease, 5, 1-6. https://doi.org/10.1016/S2222-1808(14)60617-4

[32] Vuong, Q.V., Hirun, S., Roach, P.D., Bowyer, M.C., Phillips, P.A. and Scarlett, C.J. (2013) Effect of Extraction Conditions on Total Phenolic Compounds and Antioxidant Activities of Carica papaya Leaf Aqueous Extracts. Journal of Herbal Medicine, 3, 104-111. https://doi.org/10.1016/j.hermed.2013.04.004

[33] Mohdaly, A.A.A., Smetanska, I., Ramadan, M.F., Sarhan, M.A. and Mahmoud, A. (2011) Antioxidant Potential of Sesame (Sesamum indicum) Cake Extract in Stabilization of Sunflower and Soybean Oils. Industrial Crops and Products, 34, 952-959. https://doi.org/10.1016/j.indcrop.2011.02.018

[34] Ordoñez, A.A.L., Gomez, J.D., Vattuone, M.A. and lsla, M.I. (2006) Antioxidant Activities of Sechium edule (Jacq.) Swartz Extracts. Food Chemistry, 97, 452-458. https://doi.org/10.1016/j.foodchem.2005.05.024

[35] Li, Y., Guo, C., Yang, J., Wei, J., Xu, J. and Cheng, S. (2006) Evaluation of Antioxidant Properties of Pomegranate Peel Extract in Comparison with Pomegranate Pulp Extract. Food Chemistry, 96, 254-260. https://doi.org/10.1016/j.foodchem.2005.02.033

[36] Akhtar, P., Yaakob, Z., Ahmed, Y., Shahinuzzaman, M. and Hyder, M.K.M. (2018) Total Phenolic Contents and Free Radical Scavenging Activity of Different Parts of Jatropha Species. Industrial Crops and Products, 30, 365-370.

[37] Thaipong, K., Boonprakob, U., Crosby, K., Cisneros-Zevallos, L. and Byrne, D.H. (2006) Comparison of ABTS, DPPH, FRAP, and ORAC Assays for Estimating Antioxidant Activity from Guava Fruit Extracts. Journal of Food Composition and Analysis, 19, 669-675. https://doi.org/10.1016/j.jfca.2006.01.003

[38] Gertenbach, D.D. (2016) Solid-Liquid Extraction Technologies for Manufacturing Nutraceuticals. In: Shi, J.X., Le Maguer, M. and Mazza, G., Eds., Functional Foods. Biochemical and Processing Aspects, CRC Press, Boca Raton, 331-366.

[39] Asghar, N., Naqvi, S.A., Hussain, Z., Rasool, N. and Khan, Z.A. (2016) Compositional Difference in Antioxidant and Antibacterial Activity of All Parts of the Carica papaya Using Different Solvents. Chemistry Central Journal, 10, 5. https://doi.org/10.1186/s13065-016-0149-0

[40] Maisarah, A., Nurul Amira, B., Asmah, R. and Fauziah, O. (2013) Antioxidant Analysis of Different Parts of Carica papaya. International Food Research Journal, 20, 1043-1048.

[41] Martial-Didier, A.K., Hubert, K.K., Parfait, K.E.J. and Kablan, T. (2017) Phytochemical Properties and Proximate Composition of Papaya (Carica papaya L. var Solo 8) Peels. Turkish Journal of Agriculture: Food Science and Technology, 5, 676-680. https://doi.org/10.24925/turjaf.v5i6.676-680.1154

[42] Lee S.J. (2013) Antioxidant Activity of a Novel Synthetic Hexa-Peptide Derived from an Enzymatic Hydrolysate of Duck Skin By-Products. Food and Chemical Toxicology, 62, 276-280. https://doi.org/10.1016/j.fct.2013.08.054

[43] Ahn, J.H., Jo, Y.H., Kim, S.B., Turk, A., Oh, K.E., Hwang, B.Y., Lee, K.Y. and Mi, K. (2018) Identification of Antioxidant Constituents of the Aerial Part of Plantago Asiatica Using LC-MS/MS Coupled DPPH Assay. Phytochemistry Letters, 26, 20-24. https://doi.org/10.1016/j.phytol.2018.05.006

[44] Al-Farsi, M., Al-Amri, A., Al-Hadhrami, A. and Al-Belushi, S. (2018) Color, Flavonoids, Phenolics and Antioxidants of Omani Honey. Heliyon, 4, e00874.

https://doi.org/10.1016/j.heliyon.2018.e00874 
[45] Alahyane, A., Harrak, H., Ayour, J., Elateri, I., Ait-Oubahou, A. and Benichou, M. (2019) Bioactive Compoun DS and Antioxidant Activity of Seventeen Moroccan Date Varieties and Clones (Phoenix dactylifera L.). South African Journal of Botany, 121, 402-409. https://doi.org/10.1016/j.sajb.2018.12.004

[46] Al Turki, S., Shahba, M.A. and Stushnoff, C. (2010) Diversity of Antioxidant Properties and Phenolic Content of Date Palm (Phoenix dactylifera L.) Fruits as Affected by Cultivar and Location. Journal of Food, Agriculture and Environment, 8, 253-260. https://doi.org/10.1016/j.sajb.2018.12.004 